\title{
Effect of Nursing Dysphagia Screening Tool Education on Increasing Knowledge of Documentation for Screening Results in Hospital Nurses
}

\author{
Esther Palupi, ${ }^{1}$ Yuyun Yueniwati, ${ }^{2}$ Alfrina Hany ${ }^{3}$ \\ ${ }^{1}$ Nursing Master Degree Program, Faculty of Medicine, Universitas Brawijaya, Malang, Indonesia, \\ ${ }^{2}$ Department of Radiology, Faculty of Medicine, Universitas Brawijaya, Malang, Indonesia, \\ ${ }^{3}$ School of Nursing, Faculty of Medicine, Universitas Brawijaya, Malang, Indonesia
}

\begin{abstract}
Efforts to prevent complications of dysphagia can be detected using a quick and correct screening method. Dysphagia screening tool (DST) can identify dysphagia stroke patients with eight indicators. Therefore, it makes it easier for nurses to improve their ability to document it. This study aims to analyze the effect of nursing dysphagia screening tool (NDST) education on increasing knowledge of screening documentation for hospital nurses. The research method was a quasi-experimental design with a non-equivalent control group. The research was taking place at Tk. II dr. Soepraoen Hospital Malang starting 14 July-23 July 2021. A sample of 120 nurses was selected with a total sampling of 60 controls and interventions. Bivariate data analysis applied dependent $t$ test followed by Mann-Whitney. The results showed that the mean difference of knowledge value was -19.999 with $t$ arithmetic of -8.373 and $\mathrm{p}=0.000(\mathrm{p}<0.05)$. The significance value of the control group is $\mathrm{p}=0.000(\mathrm{p}<0.05)$, which means that there is a difference before and after the action on the knowledge variable of the NDST education control group through the website link. Value of $\mathrm{p}=0.000(\mathrm{p}<0.05)$ means a difference between the increase in knowledge of the intervention group through face-to-face lectures and the website link control group. In conclusion, there are knowledge differences in documenting the results of dysphagia screening on patients with stroke before and after DST learning for hospital nurses. It is necessary to disseminate NDST learning socialization to screen for dysphagia in patients with stroke to optimize the prevention of stroke complications in the first 24 hours.
\end{abstract}

Keywords: Dysphagia, education, NDST, stroke

\section{Pengaruh Edukasi Nursing Dysphagia Screening Tool terhadap Peningkatan Pengetahuan Dokumentasi Hasil Skrining pada Perawat Rumah Sakit}

\begin{abstract}
Abstrak
Upaya pencegahan komplikasi disfagia dapat dideteksi menggunakan metode skrining yang cepat dan benar. Dysphagia screening tool (DST) dapat mengidentifikasi disfagia pasien strok dengan delapan indikator. Hal ini mempermudah perawat untuk meningkatkan kemampuannya dalam mendokumentasikannya. Tujuan penelitian ini menganalisis pengaruh edukasi nursing dysphagia screening tool (NDST) terhadap peningkatan pengetahuan dokumentasi hasil skrining pada perawat rumah sakit. Metode penelitian yang digunakan adalah quasi-experimental design dengan non-equivalent control group. Penelitian bertempat di RS Tk. II dr. Soepraoen Malang pada 14 Juli-23 Juli 2021. Sampel sebanyak 120 perawat dipilih secara total sampling, 60 kontrol dan perlakuan. Analisis data bivariat menggunakan uji t dependen dilanjutkan dengan Mann-Whitney. Hasil menunjukkan nilai mean difference pengetahuan sebesar -19,999 dengan t hitung sebesar $-8,373$ dan $\mathrm{p}=0,000(\mathrm{p}<0,05)$. Nilai signifikansi kelompok kontrol $\mathrm{p}=0,000(\mathrm{p}<0,05)$ yang berarti terdapat perbedaan sebelum dan sesudah tindakan pada variabel pengetahuan kelompok kontrol edukasi NDST melalui tautan website. Nilai $\mathrm{p}=0,000(\mathrm{p}<0,05)$ berarti terdapat perbedaan peningkatan pengetahuan kelompok perlakuan edukasi melalui ceramah tatap muka dengan kelompok kontrol tautan website. Simpulan, terdapat perbedaan pengetahuan dalam pendokumentasian hasil skrining disfagia pasien strok di RS sebelum dan sesudah dilakukan edukasi NDST pada perawat rumah sakit. Diperlukan sosialisasi edukasi NDST untuk menskrining disfagia pasien strok untuk mengoptimalkan pencegahan perburukan klinis komplikasi strok pada 24 jam pertama.
\end{abstract}

Kata kunci: Disfagia, edukasi, NDST, strok

Received: 4 August 2021; Revised: 22 December 2021; Accepted: 30 December 2021; Published: 31 December 2021

Correspondence: Esther Palupi. Nursing Master Degree Program, Faculty of Medicine, Universitas Brawijaya. Jln. Veteran, Malang 65145, East Java, Indonesia. E-mail: estherpalupi.ep@gmail.com 


\section{Introduction}

Stroke or cerebrovascular accident is a clinical condition that causes a reduction of focal neurological function in the central nervous system. ${ }^{1}$ Dysphagia has also increased with the rising stroke prevalence globally and in Indonesia. ${ }^{2}$ A study in Canada registered 55,000 cases every year, with $55 \%$ experiencing dysphagia in acute stroke patients. ${ }^{3}$ At the same time, the Indonesia Basic Health Research Report 2018 data explained that in Indonesia, the cases of dysphagia hit 2,632,000 every year. ${ }^{4}$ However, the exact number of dysphagia in East Java has not been found because most hospitals do not have standard procedures regarding dysphagia screening. The only data obtained was during the last three months in 2015. A total of 30\% of them experienced dysphagia. ${ }^{2}$

Complications of dysphagia that can threaten the life of stroke patients are the occurrence of aspiration or limitations in the ability to swallow food and fluids. Therefore, it can lead to a rising risk for lack of nutrition and hydration or pneumonia. ${ }^{5-6}$ In addition, dysphagia can increase the length of hospital stay, resulting in increased mortality, comorbidities, and increased health care costs. ${ }^{5-7}$ However, in general, dysphagia is not considered the leading cause of death, but its complications are aspiration pneumonia and malnutrition, which can cause death commonly in the elderly. ${ }^{5,7}$ Aspiration pneumonia cases that hit $40-71 \%$ will cause death in the elderly with dysphagia; this can also cause a length of stay of about $40 \%$ in all age groups. ${ }^{8}$

In performing dysphagia screening, nurses can use various tools, one of which is the nursing dysphagia screening tool (NDST). The dysphagia screening tool (DST) is a dysphagia screening tool that contains eight indicators to observe stroke patients who have difficulty swallowing. The main advantage of using this tool is that it has been designed with an easy-to-use procedure to be applied quickly and precisely by nurses as a daily routine. Furthermore, it is also effective in shortening the length of stay in the hospital and reducing the cost of treatment. ${ }^{9}$ According to previous research, NDST is more effective than other tools so that nurses can use it in accelerating their work in finding cases of dysphagia. Thus, complications from dysphagia can be prevented as early as possible..$^{10}$

This identification is vital to be carried out by hospitals to empower health workers, especially nurses, in reducing mortality due to dysphagia. The form of treatment that nurses can carry out must be accompanied by sound knowledge and attitudes to be diagnosed quickly. In general, nurses' attitudes are influenced by personal experience because they have no experience at all in screening. As a result, they tend to have a negative attitude and do not perform correctly. ${ }^{11}$ Therefore, it is essential that regular teaching is given to increase knowledge of documenting the dysphagia screening results.

The ability of nurses to document the dysphagia screening results is influenced by knowledge. $^{12,13}$ In addition, from the results of interviews with nurses who have served in the stroke unit of Tk.II dr. Soepraoen Hospital Malang, from December $18^{\text {th }}, 2020$ to January $3^{\text {rd }}$, 2021, seven people stated that they did not know how to document the action regarding dysphagia screening in patients with stroke because they had never received an education.

Nurses have a significant role in handling the first 24 hours of stroke patients, primarily to diagnose dysphagia. ${ }^{13}$ Therefore, it is essential to document it properly and correctly. The research problem is whether education influences the discrepancy of nursing dysphagia screening tools over documentation knowledge of nurses in reporting dysphagia on patients with stroke. The purpose of this study was to analyze the effect of nursing dysphagia screening tool (NDST) education on increasing knowledge of screening documentation for hospital nurses.

\section{Methods}

The research design was quantitative with a quasiexperimental design method, and the approach was a non-equivalent control group design. The population of this study was nurses who had treated stroke patients in the internal medicine ward, neuro clinical polyclinic, emergency room, stroke unit, a total of 120 people. The samples in this study were nurses who had treated stroke patients in the internal medicine ward, neuroclinical polyclinic, emergency department, and stroke unit, a total of 120 people with total sampling. The sample was divided into the intervention group (face-to-face lecturers) of 60 respondents and the control group (website) of 60 people. The independent variable was the NDST learning. The dependent variable was the 
nurses' knowledge in documenting dysphagia screening results on patients with stroke. This research was conducted in Tk. II dr. Soepraoen Hospital Malang from July $14^{\text {th }}$ to July $23^{\text {rd }}, 2021$. Data analysis used paired sample $t$ test SPSS version 20.o. The ethical approval letter from the Health Research Ethics Committee of the Faculty of Medicine Universitas Brawijaya Malang is number 190/EC/KEPK-S2/07/2021.

\section{Results}

Table 1 explained that the NDST education using the face-to-face lecturer and the control group who educated NDST using a website group's age characteristics for nurses were 25-30 years. People (46.7\%), the highest education group was the NDST face-to-face lecturer group, and the control group was 47 people $(78.3 \%)$ and 51 people (85\%), respectively. The female respondents in the NDST education face-to-face lecturer group were 46 people $(76.7 \%)$, and the control group website was 45 people (75\%). In comparison, the length of work in the face-to-face and control groups was 6-10 years.
Based on Table 2, the interpretation of the statistical t test dependent sample results was that variable of knowledge on group intervention face to face lecturer generated mean difference values amounted to -19.999 with statistic $t$ arithmetic of -8.373 and $\mathrm{p}=0.000$. The interpretation of the statistical t test dependent sample results was that variable of knowledge on website control group generated mean difference values amounted to -8.70433 with statistic $t$ arithmetic of -4.216 and $\mathrm{p}=0.000$.

\section{Discussion}

The age group of $19-34$ is a early adult category. ${ }^{14}$ This period is a period of adjustment to new life patterns and new social expectations. ${ }^{15}$ Early adults are also able to adjust independently. The range of mature emotions can be categorized as having reached the maturity level to provide the proper response according to the situation they face..$^{16,17}$ In this case, nurses must carry out the task of checking dysphagia on patients with stroke. Thus, specific skills are needed in conducting assessments, especially interpersonal

Table 1 Characteristics of NDST Educational Treatment and Control Group

\begin{tabular}{lccc}
\hline Characteristics & Groups & Category & n=120 (\%) \\
\hline Age (years) & NDST educational face to face lecturer & $25-30$ & $38(63.3)$ \\
& & $31-35$ & $5(8.3)$ \\
& & $36-40$ & $11(18.3)$ \\
& & $41-45$ & $2(3.3)$ \\
& & $46-50$ & $4(6.7)$ \\
Education & & $25-30$ & $28(46.7)$ \\
& NDST educational face to face lecturer & $31-35$ & $22(36.7)$ \\
& & $36-40$ & $10(16.7)$ \\
Gender & DIII Nursing & $47(78.3)$ \\
& & S1 Nursing & $13(21.7)$ \\
& NDST educational face to face lecturer & DIII Nursing & $51(85.0)$ \\
& & S1 Nursing & $9(15.0)$ \\
Length of working & Man & $14(23.3)$ \\
(years) & NDST educational with website & Woman & $46(76.7)$ \\
& & Man & $15(25)$ \\
& & Woman & $45(75)$ \\
& & $0-5$ & $20(33.3)$ \\
& & $6-10$ & $24(40.0)$ \\
& & $11-15$ & $11(18.3)$ \\
& & $16-20$ & $1(1.7)$ \\
& NDST educational face to face lecturer & $21-25$ & $4(4)$ \\
& & $0-5$ & $22(36.7)$ \\
& & $6-10$ & $26(43.3)$ \\
& & $11-15$ & $12(20.0)$ \\
\hline
\end{tabular}


Table 2 Research Differences in Increase Nurse Knowledge about NDST in Intervention and Control Group

\begin{tabular}{lcccccccc}
\hline Groups & Mean & SD & SE & t & df & p Value & 95\% CI & n \\
\hline $\begin{array}{l}\text { Intervention } \\
\text { group }\end{array}$ & & & & & & & & \\
$\quad$ Pre-test & 70.3723 & 21.81035 & 2.81570 & -8.373 & 59 & 0.000 & -24.77865 to -15.21935 & 60 \\
$\quad \begin{array}{l}\text { Post-test } \\
\text { Control group }\end{array}$ & 90.3713 & 9.47732 & 1.22352 & & & & & \\
$\quad$ & & & & & & & & \\
$\quad$ Pre-test & 72.9638 & 22.25756 & 2.87344 & -4.216 & 59 & 0.000 & -12.83523 to -4.57344 & 60 \\
$\quad$ Post-test & 81.6682 & 10.98245 & 1.41783 & & & & & \\
\hline
\end{tabular}

communication skills. The essential skills of interpersonal communication are expressing feelings, choosing what to do, expressing opinions, increasing self-esteem, and adapting to others. ${ }^{18}$ These are needed to detect special events as dysphagia characteristics, including dysarthria, are challenging to study, and patients tend to be discreet. Therefore, these communication skills can help nurses find signs of dysphagia symptoms as described in the DST. Another source also explained that early adulthood could have matured emotionally and controlled emotions, making it easier for one to receive new knowledge and information from the surrounding environment. ${ }^{19}$

These research references were also relevant to the results of this study, wherein researchers also found that subjective and objective data on patients with stroke could be ultimately obtained if nurses have interpersonal communication skills. These interpersonal skills are in the form of the ability to observe signs of dysphagia symptoms that have been generated from providing NDST education by researchers.

The research data showed that the NDST education treatment group's highest education and control group was DIII Nursing. The DIII Nursing education group with a higher education category aligned with research from. ${ }^{20}$ It explained that someone who has a higher education background is easier in the process of accepting new things so that in the end, it will be easier to solve problems related to these new things. Similarly, the research result from Nurhafizah et $a .^{21}$ stated that the education achieved by a person is a determinant of productivity, including knowledge, skills, abilities, attitudes, and behavior which are sufficient in carrying out their work. The results of this study were in line with the researcher's assumption that the productivity of nurses' performance could be supported by formal education of nurses. Education provides knowledge for the implementation of tasks and the basis for self-development and the ability to utilize all means, one of which is to understand the application of observing dysphagia patients with NDST.

The length of work in the treatment group in the 6-10 year range was $40 \%$, while the control group $6-10$ years was $43.3 \%$. The researcher concluded that nurses who worked at Tk.II dr. Soepraoen Hospital Malang still had few experiences. Expressed as work experience, time at work becomes a reasonable basis for predicting employee productivity. It was in line with several studies that state the longer you work, the more experiences you will get and the more cases you will handle, making someone more skilled and thorough in completing work. ${ }^{21-24}$

Table 2 explained that the statistical test sample pair results showed that the value of the mean difference of knowledge amounted to -19.999 by statistic $t$ arithmetic of -8.373 and $\mathrm{p}=0.000(\mathrm{p}<0.05)$. It meant a difference in the average on the variable understanding of group intervention education NDST between the values before and after the performed treatment. The difference is because the level of knowledge must go through several processes; the stages of knowing, understanding, and applying what one knows. ${ }^{25}$ In this case, the knowledge about documenting dysphagia screening results and a nurse's daily routine.

The cognitive level of knowledge includes knowing, understanding, applying, analyzing, synthesizing, and evaluating. ${ }^{26}$ It may be drawn a common thread that before someone can apply the knowledge he has, one must know and understand something first. As one of the actors of nursing documentation, nurses have a 
significant role in caring for and conveying the patient's condition to other disciplines in the hospital. They need to have good knowledge and understanding of the documentation. Therefore, nurses must continuously improve their abilities through training or attending formal and non-formal education organized by hospital institutions to enhance their work productivity. In addition, it must also be noted that the workload for nurses has to be considered. Nurses often need extra time to complete their tasks, so that time for work must be in harmony with work productivity in direct health services.

The researcher concluded that was a difference between the study results before and after the NDST education, meaning that the educational intervention carried out by the researcher had good influences on nurses. The positive impact of education could be influenced by the high work motivation of nurses so that the tendency to burn out on their duties in carrying out dysphagia screening was low. It was in line with research from Wahyudi and Gunarto, ${ }^{25}$ which explained that the low work motivation of nurses could result in burnout, so it affects the work productivity of nurses. Work ethic has a 4.8 times greater opportunity to support work productivity. ${ }^{26}$ Another source also stated that high work motivation of nurses would improve the performance of nurses so that each task will be carried out correctly. ${ }^{27}$ The tendency of a strong desire for something can make a person try and pursue something and gain more profound knowledge. ${ }^{28}$ Thus, hospital stakeholders need to pay attention to motivational factors in increasing the knowledge and skills of nurses in carrying out dysphagia screening of stroke patients to prevent further clinical deterioration.

\section{Conclusion}

In conclusion, there are discrepancies in the average on the variable knowledge of group treatment education NDST between the values before and after the performed treatment for hospital nurses.

\section{Conflict of Interest}

The authors have no conflict of interest to declare.

\section{Acknowledgment}

The researcher would like to thank all respondents who participated in this study.

\section{References}

1. Coupland AP, Thapar A, Qureshi MI, Jenkins H, Davies AH. The definition of stroke. J R Soc Med. 2017;110(1):9-12.

2. Achmad BF, Nuraeni A, Arifin MZ. Perbedaan efektivitas terapi menelan berdasarkan karakteristik demografi pasien disfagia stroke. JKKK. 2017;1(2):120-30.

3. Sherman V, Flowers H, Kapral MK, Nicholson G, Silver F, Martino R. Screening for dysphagia in adult patients with stroke: assessing the accuracy of informal detection. Dysphagia. 2018;33(5):662-9.

4. Badan Penelitian dan Pengembangan Kesehatan, Kementerian Kesehatan Republik Indonesia. Laporan Nasional Riskesdas 2018. Jakarta: Lembaga Penerbit Badan Penelitian dan Pengembangan Kesehatan; 2019.

5. Sura L, Madhavan A, Carnaby G, Crary MA. Dysphagia in the elderly: management and nutritional considerations. Clin Interv Aging. 2012;7:287-98.

6. Cohen DL, Roffe C, Beavan J, Blackett B, Fairfield CA, Hamdy S, et al. Poststroke dysphagia: a review and design considerations for future trials. Int J Stroke. 2016;11(4):399-411.

7. Hines S, Kynoch K, Munday J. Nursing interventions for identifying and managing acute dysphagia are effective for improving patient outcomes: a systematic review update. J Neurosci Nurs. 2016;48(4):215-23.

8. Martino R, Maki E, Diamant N. Identification of dysphagia using the Toronto Bedside Swallowing Screening Test (TOR-BSST $\left.{ }^{\odot}\right)$ : are 10 teaspoons of water necessary? Int $\mathrm{J}$ Speech Lang Pathol. 2014;16(3):193-8.

9. Mandysová P. A vision for dysphagia screening by nurses. Ošetrovatel'stvo. 2014; 4(1):39-43.

10. Wangen T, Hatlevig J, Pifer G, Vitale K. Preventing aspiration complications: implementing a swallow screening tool. Clin Nurse Spec. 2019;33(5):237-43.

11. Bizimana E, Bimerew M. Knowledge, attitudes and barriers of nurses on benefits of the quality of patient record-keeping at selected public district hospitals in Burundi. IJANS. 2021;14:100266. 
12. Tasew H, Mariye T, Teklay G. Nursing documentation practice and associated factors among nurses in public hospitals, Tigray, Ethiopia. BMC Res Notes. 2019;12(1):612.

13. Rhoda A, Pickel-Voight A. Knowledge of nurses regarding dysphagia in patients post stroke in Namibia. Curationis. 2015;38(2):1564.

14. Franssen T, Stijnen M, Hamers F, Schneider F. Age differences in demographic, social and health-related factors associated with loneliness across the adult life span (1965 years): a cross-sectional study in the Netherlands. BMC Public Health. 2020; 20(1):1118.

15. Dewina S, Suganda O, Widiantie R. Pengaruh model pembelajaran problem based learning (PBL) terhadap kemampuan menganalisis dan keterampilan berargumentasi siswa pada konsep pencemaran lingkungan di kelas X. Quagga. 2017;9(2):46-54.

16. Hurlock EB. Developmental psychology: a life-span approach. $5^{\text {th }}$ Edition. New York: McGraw Hill Education; 2017.

17. Häggman-Laitila A, Salokekkilä P, Karki S. Relationship of self concept, problem solving and self adjustment in youth. Child Youth Care Forum. 2019;48(5):633-61.

18. Romppanen J, Häggman-Laitila A. Interventions for nurses' well-being at work: a quantitative systematic review. J Adv Nurs. 2017;73(7):1555-69.

19. Putri AF. Pentingnya orang dewasa awal menyelesaikan tugas perkembangannya. SCHOULID Indones J School Counceling. 2018;3(2):35-40.

20. Risnah, Rosmah, Mustamin, Sofingi I. Pengaruh pelatihan terhadap pengetahuan tentang gizi buruk dan inter-professional collaboration petugas puskesmas. J Kesehat. 2018;11(1):61-71.

21. Nurhafizah R, Hastuti MF, Fauzan S. Analisa pengetahuan perawat mengenai penerapan dokumentasi terintegrasi di Rumah Sakit Universitas Tanjungpura. TJNPE. 2019;1(2): 35894 .

22. Hazriyanto, Ibrahim B, Silitonga F. Organizational commitment, satisfaction and performance of lecturer (model regression by gender of man). IRMM. 2019;9(2):40-4.

23. Apriluana G, Khairiyati L, Setyaningrum R. Hubungan antara usia, jenis kelamin, lama kerja, pengetahuan, sikap dan ketersediaan alat pelindung diri (APD) dengan perilaku penggunaan APD pada tenaga kesehatan. J Publikasi Kesehat Masy Indones. 2016;3(3): 82-7.

24. Manoochehri H, Imani E, AtashzadehShoorideh F, Alavi-Majd A. Competence of novice nurses: role of clinical work during studying. J Med Life. 2015;8(Spec Iss 4):328.

25. Wahyudi CT, Gunarto CS. Produktivitas kerja perawat ruang rawat inap. JIIKI. 2019;9(1):550-62.

26. Sani N. Hubungan antara disiplin kerja, lingkungan kerja dan etos kerja dengan produktivitas kerja perawat di ruang rawat inap RS Pertamina Bintang Amin Bandar Lampung tahun 2018. JIKK. 2019;6(3):18693.

27. Putri IRR, Rosa EM. Analisis motivasi kerja perawat di ruang rawat inap RS PKU Muhammadiyah Yogyakarta Unit II. J Ners Kebidanan Indones. 2015;3(2):82-90.

28. Sugiyati S. Hubungan pengetahuan perawat dalam dokumentasi keperawatan dengan pelaksanaannya di rawat inap RSI Kendal. In: Prosiding Seminar Nasional \& Internasional 2014: Prosiding Konferensi Nasional PPNI Jawa Tengah; 2014 May 24; Semarang, Indonesia. Semarang: Universitas Muhammadiyah Semarang; 2014 [cited 2021 July 11]. p. 298-207. 